Article

\title{
Examining the Structural Relationships among Heritage Proximity, Perceived Impacts, Attitude and Residents' Support in Intangible Cultural Heritage Tourism
}

\author{
Yuqian Wei, Hengyu Liu and Keun-Soo Park * \\ Department of Leisure Service \& Sports, Pai Chai University, 155-40 Baejae-ro (Doma-Dong), Seo-Gu, \\ Daejeon 35345, Korea; 18317859263@163.com (Y.W.); liu1184632365@gmail.com (H.L.) \\ * Correspondence: kspark5@pcu.ac.kr
}

Citation: Wei, Y.; Liu, H.; Park, K.-S. Examining the Structural

Relationships among Heritage

Proximity, Perceived Impacts, Attitude and Residents' Support in Intangible Cultural Heritage Tourism Sustainability 2021, 13, 8358. https:// doi.org/10.3390/su13158358

Academic Editor: Andrea Pérez

Received: 22 June 2021

Accepted: 23 July 2021

Published: 27 July 2021

Publisher's Note: MDPI stays neutral with regard to jurisdictional claims in published maps and institutional affiliations.

Copyright: (c) 2021 by the authors. Licensee MDPI, Basel, Switzerland. This article is an open access article distributed under the terms and conditions of the Creative Commons Attribution (CC BY) license (https:// creativecommons.org/licenses/by/ $4.0 /)$.

\begin{abstract}
Among the many methods of revitalizing intangible cultural heritage (ICH), tourism undoubtedly has the largest social and economic benefits. Taijiquan, also known as Tai Chi, was included in the Representative List of the Intangible Cultural Heritage of Humanity in December 2020. It provides the local destination with a unique selling point for strengthening local tourism competitiveness. The research on the relationship between the heritage proximity and residents' perceived impacts to $\mathrm{ICH}$ tourism is not sufficient within the tourism literature, whereas they have recently attracted numerous interests worldwide. In response, this study aims to examine the relationships among residents' heritage proximity, perceived impacts of ICH tourism, attitude and support. Structural equation modelling has been performed and a total of 262 residents were investigated in Wen County, China. Results indicates that residents' heritage proximity has positive influence on perceived positive impacts, while has no influence on perceived negative impacts. Residents' heritage proximity and perceived impacts significantly influence their attitude, so that to influence residents' support for tourism development. This study makes a significant theoretical contribution to the ICH tourism literature. Furthermore, this study has a number of practical implications for the local departments of tourism and ICH.
\end{abstract}

Keywords: heritage proximity; perceived impacts; attitude; community support; heritage tourism

\section{Introduction}

Intangible cultural heritage (ICH), as a combination of human civilization and wisdom [1], contains the spiritual value, imagination, and cultural consciousness of a destination [2], and plays an important role in the country, society, community and residents' life $[3,4]$. ICH is created, carried and transmitted by community [5]. While, the ICH giving each community its sense of identity and continuity [6]. In fact, among the many methods of revitalizing $\mathrm{ICH}$, heritage tourism undoubtedly has the largest social and economic benefits [7]. ICH provides a destination with a unique selling point for strengthening local cultural heritage tourism competitiveness and creating positive socio-economic impacts for the community $[8,9]$.

However, the prominent commercial nature of tourism products is mutually exclusive with the cultural core of the ICH, which will lead to a series of academic questions including heritage tourism contradicts the goals of preservation and conservation of heritage [10], how to balance the relationship between the tourism industry and heritage destination residents [9], and preventing $\mathrm{ICH}$ to be easily commodified into a tourism product that satisfies tourists [11]. To a varying extent, the tourism industry may put pressure on $\mathrm{ICH}$ due to the complex relationship between tourism developers and local residents. The development of sustainable tourism in ICH sites not only depends on the quality of resources and the market size, but also on the understanding and support of the community [12]. The destination residents' voice should be heard because they would not allow tourism 
development making threats to the local cultural heritage [13]. In other words, if mutual ground between the related stakeholders can be found, the local community's resources can be preserved and heritage tourism can be sustainable [14].

Community plays a vital role in the sustainable development of heritage tourism. From the perspective of the social exchange theory (SET), community's attitudes and support for the tourism industry is based on their evaluation of the benefits and costs of tourism development $[15,16]$. Residents' perceived impacts of tourism development can affect their attitudes and support. Specifically, when residents believe that tourism benefits are higher than the negative impacts, they may support tourism development [17]. Meanwhile, residents with different heritage proximity have different perceived impacts [18]. However, there is little research on heritage proximity in tourism field and exploring ICH as a sustainable tourism resource.

Taijiquan (Tai Chi), the famous traditional Chinese martial art, has been included in the Representative List of the Intangible Cultural Heritage of Humanity in December 2020 [19]. In China, the popularity of Taijiquan is obvious. However, as the birthplace of Taijiquan, Wen County is not yet widely known, except to martial arts enthusiasts. Even so, more than three million tourists and over 5000 martial arts enthusiasts visit the area every year to study and travel. With Taijiquan becoming a world intangible cultural heritage, Wen County's popularity has expanded and its tourism industry has huge potential. Therefore, the sustainable development of intangible cultural heritage tourism in Wen County should be taken into account. As one of the stakeholders, the role of residents in intangible cultural heritage tourism cannot be ignored. Therefore, with a sample of residents in the Taijiquan heritage site, the present study aimed to: (1) examine the relationships among residents' heritage proximity, perceived impacts, attitude and community support, and (2) test the influence of perceived impacts and attitude as mediators. From the perspective of academia, this study would enrich the literature of heritage proximity in tourism field by making a new theoretical model of heritage proximity and residents' support. As far as practical implications are concerned, by utilizing the findings of this study, managers can effectively influence residents' perception to create a positive level of attitude and support by maximizing their proximity to the ICH.

\section{Literature Review}

The revival of cultural heritage has not only enhanced national confidence, but also promote the sustainable development of cultural heritage. The close relationship between intangible cultural heritage and tourism has been attracted increasing interests since the beginning of the 21st century [20]. Chinese scholars believed that the positive development of intangible cultural heritage tourism can bring market demand and economic value to the destination, promote its integration into modern social life, and is an important means for heritage protection and utilization [21,22]. Su [23] stated that heritage tourism must first break the opposition between protection and development, and establish a comprehensive way to development heritage tourism. Lin and Lian [24] proposed a heritage tourism development evaluation system from three aspects: tourism resource, experience, and tourism development conditions. However, the development of intangible cultural heritage tourism lacks the exploration of cultural connotations [21,22]. In the absence of scientific management and effect feedback mechanisms, as a result, intangible cultural heritage tourism is easy to face the market (e.g., the "only commercialization" of handicraft intangible cultural heritage, and the "only staged" performance of intangible cultural heritage) [25]. Furthermore, Lan et al. [26] believes that the essence of "protection" is to emphasize and strengthen the inherent life value of heritage, and enhance its "sustainable development" ability. On the basis of reflecting the authenticity of culture, managers should promote the transformation of traditional culture into modern life, and strengthen the "symbiotic" relationship between intangible cultural heritage and residents' lives [27]. Heritage tourism should consequently seek a balance between development and protection to realize the effective utilization and inheritance of intangible cultural heritage resources. 
Understanding the residents' perception of the local heritage has the importance on obtaining their support for tourism development [28]. Heritage proximity helps residents' achieve an effective empowerment and foster their sense of belonging to the local community $[29,30]$. In tourism development, special cultural heritage can affect the image of the destination, and the importance of heritage proximity to enhance the happiness of local residents also exists [31]. Heritage tourist destinations will attract many tourists who are interested in local cultural heritage, which increases local income [32,33], provides a platform for the exchange of social and cultural values between residents and tourists [34], and protects local culture heritage [35]. On the other side of the coin, tourism development will also bring a series of negative impacts on the destination, such as traffic congestion, noise and light pollution [33]. The spatial resources of the destination will be squeezed due to the increase in the number of tourists, which may cause conflicts between tourists and residents and decrease the quality of life of residents [34].

Interestingly, in previous studies, "proximity" was usually divided into two meanings. One is the concept of "spatial proximity" originally used in geographical and spatial research [36,37], and is regarded as the distance between the place where the residents live and attractions in tourism research [38]. Previous studies have shown that spatial proximity has a significant effect on the residents' perception of tourism impact and their attitude toward tourism [39]. For example, Belisle and Hoy [40] suggested that as distance from the tourist zone increases, the impact of tourism is perceived less favorably [41]. In other words, the closer the residents are to the attractions, the stronger their perception of the impact of tourism. In addition, some scholars point out that the closer the residents are to the attractions the stronger their perception of the negative impact of tourism [42]. Another concept is "organized proximity" proposed by Torre and Rallet [36], not geographical, but relational. It refers to belongingness or personal identification with - belonging to-a particular entity such as neighborhood, organization, and other units including heritage objects as facilitated by culture, rules, norms, or routines. Uriely et al. [43] introduced the concept of "heritage proximity" in the field of heritage research, based on the perceptual notion of proximity from geography, and defined it as the perceptual distance between residents and heritage promotion in a particular location. According to the identity and material culture theoretical frameworks, Lwoga [44] pointed out that heritage perceptual proximity as the notion of identity, means the result of individual and collective (society), and cultural materials/objects interactions, in individual's interpretation of the self. In this study, the concept of "heritage proximity" is used to measure the self's interpretation of the perceptual distance between the residents of a specific location and the intangible cultural heritage.

Attitude toward tourism is defined as a psychological tendency that the local residents have by evaluating the impacts (benefits/advantages and costs/disadvantages) of tourism development with some degree of favor [44]. With more and more attention paid to the role of residents in tourism, residents' attitudes have been studied in the context of urban tourism [45,46], rural tourism [47,48], eco-tourism [49], heritage tourism [50,51] and so on. As an important determinant of residents' attitude towards tourism development, the "heritage proximity" was investigated only under the unique conditions of religious heritage in the Middle East and Kale ruins site in Tanzania [18,43]. By relying on the case study of Nazar, Uriely, Israeli and Reichel [43] believed that "heritage proximity" could be considered as one of the factors that determine resident attitudes toward such site development, and suggested that identification with what is promoted could generate positive attitudes toward tourism development. Lwoga [18] proposed that perceptual heritage proximity has significant impact on residents' attitudes to positive and negative impacts of tourism, which in turn influence residents' support for tourism. Further, he explored the moderating effect of residents' spatial proximity to heritage on the relationship between their perceptual proximity to heritage and tourism attitudes [44]. The results indicated that heritage proximity has direct impacts on residents' perception of positive 
and negative impacts, and relates positively and significantly to attitude. Therefore, the following hypotheses are proposed:

Hypothesis 1 (H1). The heritage proximity has a positive effect on perceived positive impacts.

Hypothesis 2 (H2). The heritage proximity has a negative effect on perceived negative impacts.

Hypothesis 3 (H3). The heritage proximity has a positive effect on attitude.

Most of the studies on attitude used social exchange theory (SET) as the theoretical basis to explain the antecedents and consequences of residents' attitudes [52]. The core point of SET is that a basic form of human interaction is the exchange of social and material resources, and people always hope to maximize the value of the exchange results $[53,54]$. In the context of tourism, SET usually contains three elements: benefits, cost, and exchange process. In some studies, "economic", "social-cultural" and "environmental" are taken as the three dimensions of benefits and costs [55-57]. For example, Özel and Kozak [58] identified three main influencing dimensions through the analysis of the interview content of Cappadocia residents. The result shows that the economic impact is more obvious because the respondents pay more attention to the economic impact. This finding agrees with those of Abdollahzadeh and Sharifzadeh [59] and Jani [60]. In addition, more scholars choose perceived "positive impact" (e.g., investment opportunities, infrastructure improvement, promotion of cultural identity, etc.) and "negative impact"(e.g., traffic congestion, noise, the rising cost of land, social security problems and so on) to represent benefits and costs respectively [51,61-63]. The relationships between residents' attitudes concerning positive and negative impacts of tourism and support for tourism development were analyzed in different tourism contexts. If residents believe that the value or significance of tourism development is positive for the community, they will have a positive emotional connection with the local tourism development $[64,65]$. For example, the research result of Ribeiro, Pinto, Silva and Woosnam [62] shows a direct positive relationship between positive impact and pro-tourism behavior and a direct negative relationship between negative impact and pro-tourism behavior. Tourism development might lead to changes in residents' attitudes, their lifestyles, social networks, and living environment [66]. Community residents' views and attitudes towards tourism development play a vital role on the successful development, marketing and operation of present and future tourism projects [51]. When the perceived benefit of residents is greater than the cost, it may lead to their positive attitude towards tourism development, otherwise on the contrary [67]. Such surveys are conducive to setting up programs to minimize friction between tourists and residents, and to formulate plans to gain resident support of tourist development. Therefore, the following hypotheses are proposed:

Hypothesis 4 (H4). The perceived positive impacts has a positive effect on attitude.

Hypothesis 5 (H5). The perceived negative impacts has a negative effect on attitude.

Hypothesis 6 (H6). The perceived positive impacts has a positive effect on community support.

Hypothesis 7 (H7). The perceived negative impacts has a negative effect on community support.

Hypothesis 8 (H8). The attitude has a positive effect on community support.

Based on the above discussion and SET, our proposed framework (Figure 1) considers that residents' attitude and support for the development ICH tourism is affected by their heritage proximity and evaluation of perceived tourism impacts. The heritage proximity of resident directly influences their perceived tourism impacts. 


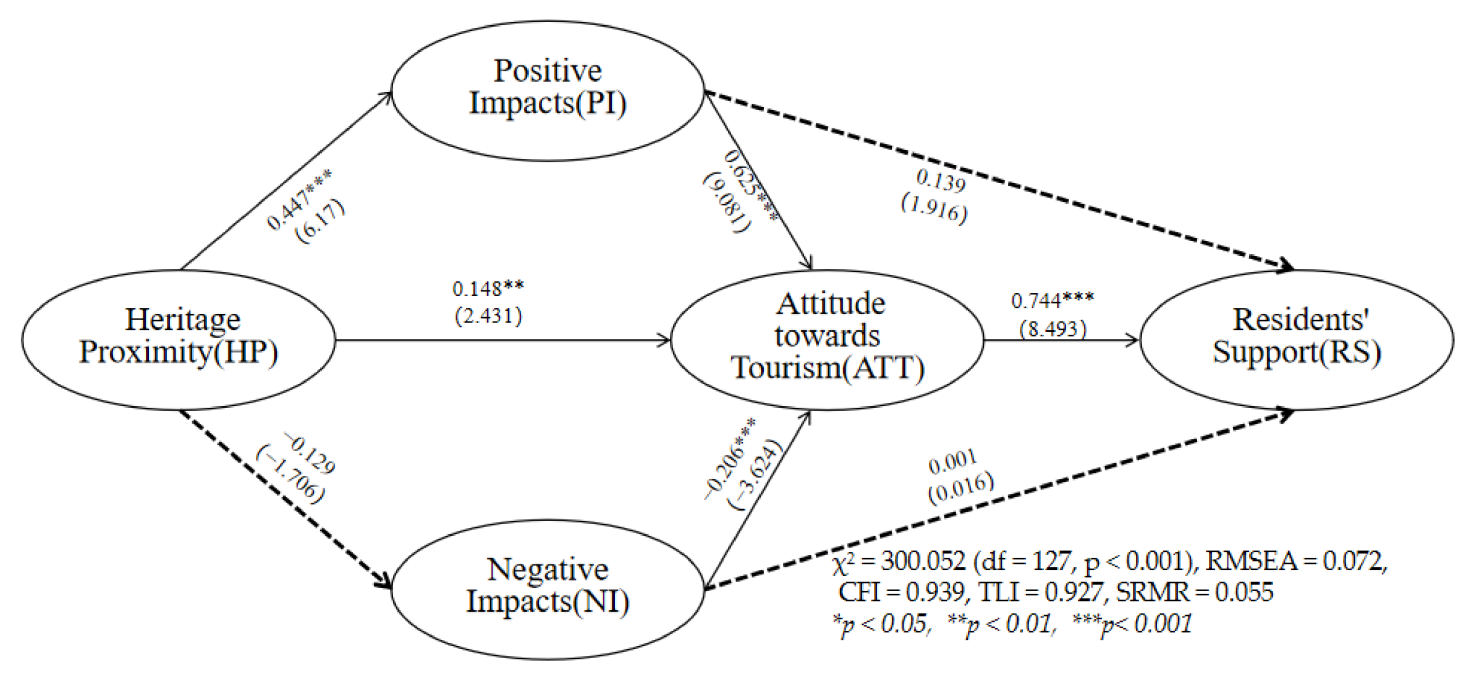

Figure 1. Results of the Structural Model.

\section{Method}

\subsection{Study Location}

Wen County, located in Henan Province, China, and with 468,000 residents, is the birthplace of Taijiquan. In recent years, Wen County has devoted itself to the promotion of Taijiquan and its culture. Correspondingly, the activation of Taijiquan cultural heritage provides a distinctive project subject and cultural carrier for the county's tourism development. Relying on the golden signboard of Taijiquan cultural heritage, the county continues to implement the "Taijiquan+" strategy to build a global tourism development pattern centered on Taijiquan culture. In Chenjiagou (a small village in Wen County), the origin of Tai Chi, more than $80 \%$ of the residents practice Taijiquan. The number of tourists in the village exceeds 3 million every year, and 5000 Taijiquan enthusiasts accept teachers to learn skills every year [68].

\subsection{Questionnaire Development}

Valid and reliable measurement variables were derived from a thorough review of the literature concerning the related constructs and topics. A self-reported questionnaire was used to survey residents living in the birthplace of Taijiquan-Wen County, China. The self-reported questionnaire consisted of four sections: Firstly, heritage proximity scale including four items was adapted from studies of $[18,44]$. Secondly, items to measure perceived impacts of tourism development were borrowed from the study of Lin et al. [69] and Stylidis et al. [70]. It includes two dimensions: perceived positive impacts with four items and perceived negative impacts with three items. Thirdly, attitude was assessed with four items from Liang and Hui [71]. Finally, resident's support was evaluated using three items $[69,70]$. All items were measured by using a 5-point Likert-type scale ranging from 1 $=$ "strongly disagree" to $5=$ "strongly agree".

\subsection{Sampling and Data Collection}

A pilot study was conducted to ensure the quality of sampling process. Since the indicators originated from English-speaking regions, the self-administered questionnaire had to be translated into Chinese. An English lecturer at Henan University was invited to translate the questionnaire, and two professors in the field of tourism in Henan University were also invited to check whether the translation and terminology expressions of the questionnaire were accurate. Then, on 5 May 2021, this study randomly asked 35 residents of Wen County to fill in the self-administered questionnaires. Based on their feedback about comprehension, expression clarity, and length, the questionnaire was revised again, and Cronbach's alphas of the constructs exceeded the minimum value of 0.70 [72], indicating the reliability of the instrument was good. 
The target population of this study was residents who lived in Wen County, China. Wen County has vigorously promoted Taijiquan and its culture in recent years. The revitalization of Taijiquan cultural heritage has provided a distinctive project subject and cultural carrier for the local tourism development. Furthermore, one doctors majoring in leisure service at Pai Chai University and two masters majoring in tourism management at Henan University distributed questionnaires to residents of Wen County, All investigators have relevant professional background. The target respondents had to be permanent residents and above 18 years of age. To guarantee the randomness of samples, questionnaires were collected both in main streets with large streams of people (one respondent per 10 people and per household) to cover urban and suburban areas. Using random sampling, the data were collected from 9 May 2021 to 15 May 2021. Finally, 357 questionnaires were distributed and a total of 262 completed questionnaires were finally used for data analysis after excluding invalid questionnaires (respondents who gave the same evaluation points to all the indicators, questionnaires were completed hastily, or questionnaire existed missing values). When using the structural equation modelling (SEM), a sample size of more than 200 is usually required, or each indicator should match at least 10 samples. As 262 (>200) samples were collected and with 18 overall indicators $(262>18 \times 10=180)$, the retained samples were sufficient for subsequent data analysis [73,74].

\subsection{Data Analysis}

Data were analyzed in several steps using Statistical Product and Service Solutions (SPSS) version 23.0 and AMOS 23.0. The SPSS program was used to perform several data screening procedures, conducted descriptive analyses to measure the means and standard deviations of constructs, and gather demographic and employment information of respondents. After measuring the reliability of each construct (internal consistency) by Cronbach's alpha analysis $[75,76]$, both for evaluating common method variance issues and for validating the measurement model, confirmatory factor analysis (CFA) was performed $[77,78]$. Then, structural equation modeling (SEM) was employed to test the hypothesized relationships.

\section{Results}

\subsection{Demographic Profile}

This survey was investigated in a region known for ICH to ensure that residents there could often access information about Taijiquan. Respondents' demographic characteristics are listed in Table 1 . The sample was comprised of more female respondents $(56.5 \%)$ than male (43.5\%). Individuals between 30 and 39 years old dominated the sample, accounting for $40.5 \%$, followed by the ages between 50 and 59 (22.9\%). Most respondents had completed higher education, such as at college $(37.8 \%)$ or university $(31.3 \%)$. Among the respondents, $92.4 \%$ reported living in the of Wen County, with the remainder residing in Jiaozuo city (outside the Wen County) or other cities. The respondents' income level was rather low, with almost a half of the respondents earning a monthly income of $¥ 2001-4000$. Official from government (29.0\%), business manager $(17.2 \%)$ and retired or no job (16.8\%) were predominant occupations of the residents.

\subsection{Measurement Model}

First, a confirmatory factor analysis (CFA) was initially conducted by using IBM AMOS 23.0 with a maximum likelihood estimation to measure items' convergent validity, and discriminant validity. The fit indices indicate that the external model fit was acceptable with $\chi^{2}(261)=297.723(p<0.05), \chi^{2} / \mathrm{df}=2.382, \mathrm{CFI}=0.940, \mathrm{NNFI}=0.926, \mathrm{TLI}=0.926, \mathrm{RMSEA}=$ 0.073 , and SRMR $=0.054$ [79-81]. Following the establishment of the measurement model, reliability and validity of the resulting factors were assessed. As depicted on Table 2, factor loadings are higher than 0.60 (ranging from 0.68 to 0.92 ) and significant at 0.001 level, which confirmed the indicator validity. 
Table 1. Damagrapgic Characteristics of Respondents $(n=262)$.

\begin{tabular}{|c|c|c|c|c|c|}
\hline Characteristics & $n$ & $\%$ & Characteristics & $n$ & $\%$ \\
\hline Gender & & & Age & & \\
\hline male & 114 & 43.51 & Younger than 20 & 4 & 1.53 \\
\hline female & 148 & 56.49 & $20-29$ & 43 & 16.41 \\
\hline Education & & & $30-39$ & 106 & 40.46 \\
\hline High school or below & 63 & 24.05 & $40-49$ & 38 & 14.5 \\
\hline College & 99 & 37.79 & $50-59$ & 60 & 22.9 \\
\hline University & 82 & 31.3 & 60 years and older & 11 & 4.2 \\
\hline Postgraduate & 18 & 6.87 & Income & & \\
\hline Occupation & & & Less than RMB 2000 & 45 & 17.18 \\
\hline $\begin{array}{l}\text { Official from } \\
\text { government }\end{array}$ & 76 & 29.01 & RMB 2001-4000 & 121 & 46.19 \\
\hline Technician/academician & 18 & 6.87 & RMB 4001-6000 & 55 & 21 \\
\hline Business manager & 45 & 17.18 & RMB 6001-8000 & 14 & 5.34 \\
\hline Service and salesperson & 5 & 1.91 & More than RMB 8001 & 27 & 10.31 \\
\hline Worker & 6 & 2.29 & Location & & \\
\hline Student & 13 & 4.96 & Wen County & 242 & 92.37 \\
\hline Farmer & 33 & 12.6 & Jiaozuo (outside of Wen County) & 7 & 2.67 \\
\hline Retired or no job & 44 & 16.79 & Jiaozuo (outside of Wen County) & 7 & 2.67 \\
\hline Other & 22 & 8.4 & Outside of Jiaozuo & 13 & 4.96 \\
\hline
\end{tabular}

Table 2. The CFA of the measurement model. ICH: Intangible Cultural Heritage.

\begin{tabular}{|c|c|c|c|}
\hline Factors/Items & Factor Loading & T-Value & $\mathbf{R}^{2}$ \\
\hline \multicolumn{4}{|l|}{ Factor 1: Heritage proximity } \\
\hline Taijiquan means a lot to me. & 0.794 & $\mathrm{~N} / \mathrm{A}$ & 0.633 \\
\hline I strongly agree with Taijiquan cultural heritage. & 0.811 & 12.876 & 0.652 \\
\hline Taijiquan and its cultural heritage remind me of regional history. & 0.713 & 11.381 & 0.512 \\
\hline I think Taijiquan and its cultural heritage are part of me. & 0.708 & 11.293 & 0.502 \\
\hline \multicolumn{4}{|l|}{ Factor 2: Perceived positive impacts } \\
\hline \multirow{2}{*}{\multicolumn{4}{|c|}{$\begin{array}{l}\text { The development of ICH tourism could have positive impacts by ... } \\
\text { developing the regional economy and increasing employment opportunities. }\end{array}$}} \\
\hline & 0.834 & $\mathrm{~N} / \mathrm{A}$ & 0.695 \\
\hline improving the regional infrastructure and recreational facilities. & 0.862 & 17.214 & 0.743 \\
\hline increasing active social, cultural and recreational activities. & 0.917 & 18.845 & 0.84 \\
\hline inheriting and developing the ICH. & 0.758 & 14.183 & 0.574 \\
\hline \multicolumn{4}{|l|}{ Factor 3: Perceived negative impacts } \\
\hline \multicolumn{4}{|l|}{ The development of ICH tourism could have negetive impacts by ... } \\
\hline destroyling the local natural ecology. & 0.807 & $\mathrm{~N} / \mathrm{A}$ & 0.652 \\
\hline traffic congestion. & 0.711 & 9.183 & 0.507 \\
\hline increasing the number of local crimes. & 0.678 & 9.009 & 0.46 \\
\hline \multicolumn{4}{|l|}{ Factor 4: Attitude } \\
\hline The development of ICH tourism generally has more advantages than disadvantages. & 0.792 & $\mathrm{~N} / \mathrm{A}$ & 0.623 \\
\hline The future of local area as a tourist attraction is bright and sustainable. & 0.9 & 16.367 & 0.81 \\
\hline The development of ICH tourism should be the focus of the local government agenda. & 0.79 & 13.938 & 0.624 \\
\hline Tourism development should be directly related to Taijiquan cultural heritage. & 0.733 & 12.675 & 0.534 \\
\hline \multicolumn{4}{|l|}{ Factor 5: Residents' Support } \\
\hline $\begin{array}{c}\text { I think we should actively encourage the development of Taijiquan cultural heritage } \\
\text { tourism in local area. }\end{array}$ & 0.854 & $\mathrm{~N} / \mathrm{A}$ & 0.723 \\
\hline I would give people a positive message about Taijiquan and its cultural heritage. & 0.808 & 15.318 & 0.658 \\
\hline I would support the government's tourism development policy. & 0.829 & 15.89 & 0.684 \\
\hline
\end{tabular}

Moreover, the composite reliability (CR) values ranged from 0.78 to 0.91 and the average variance extracted (AVE) ranged from 0.54 to 0.72 , above the recommended cut-off value of 0.70 and 0.50 , respectively [82] (as shown in Table 3). These findings suggest a mutually valid and reliable measurement model. Furthermore, the square root of AVE of all constructs exceeded the correlations between the constructs, providing evidence that 
all the constructs in the model were deemed to have a tenable discriminant validity [83]. Lastly, all constructs' Cronbach Alpha $(\alpha)$ were greater than the recommended cut-off criterion of 0.70 , showing that all the latent factors have good measurement reliability [84].

Table 3. Results of Inter-Factor Correlations of Measurement Model.

\begin{tabular}{cccccc}
\hline & HP & PI & NI & ATT & SUP \\
\hline HP & 1.00 & & & & \\
PI & 0.465 & 1.00 & & & \\
NI & -0.139 & -0.094 & 1.00 & & \\
ATT & 0.438 & 0.721 & -0.277 & 1.00 & \\
SUP & 0.456 & 0.681 & -0.226 & 0.857 & 1.00 \\
$\alpha$ & 0.828 & 0.901 & 0.774 & 0.877 & 0.868 \\
CR & 0.848 & 0.909 & 0.778 & 0.88 & 0.87 \\
AVE & 0.599 & 0.718 & 0.542 & 0.65 & 0.691 \\
\hline
\end{tabular}

\subsection{Structural Model}

Following the measurement model demonstrated overall good fit, the structural equation model (SEM) was examined with the bootstrapping maximum likelihood approach to test and evaluate eight hypotheses. Results indicated that the SEM fit the data well with $\chi^{2}=300.052, \mathrm{df}=127 ; \chi^{2} / \mathrm{df}=2.363 ; p<0.001$; TLI $=0.927 ;$ CFI $=0.949 ;$ RMSEA $=0.072$; and SRMR $=0.055$. The model explained a substantial $20 \%, 2 \%, 56 \%$ and $72 \%$ of the variance in perceived positive impacts, perceived negative impacts, attitude and community support, respectively. The proposed hypotheses were assessed and findings are depicted in the Table 4, five of the eight proposed hypotheses were significant in the expected direction, whereas $\mathrm{H} 2, \mathrm{H} 5$ and $\mathrm{H} 7$ were rejected.

Table 4. Hypothesis test.

\begin{tabular}{|c|c|c|c|c|}
\hline \multicolumn{2}{|c|}{ Hypotheses } & \multirow{2}{*}{$\begin{array}{c}\text { Coefficients } \\
0.447^{* * *}\end{array}$} & \multirow{2}{*}{$\begin{array}{c}\text { T-Values } \\
6.17\end{array}$} & \multirow{2}{*}{$\begin{array}{c}\text { Results } \\
\text { Accepted }\end{array}$} \\
\hline $\mathrm{H} 1$ & $\mathrm{HP} \rightarrow \mathrm{PI}$ & & & \\
\hline $\mathrm{H} 2$ & $\mathrm{HP} \rightarrow \mathrm{NI}$ & -0.129 & -1.706 & Rejected \\
\hline $\mathrm{H} 3$ & $\mathrm{HP} \rightarrow \mathrm{ATT}$ & $0.148^{* *}$ & 2.431 & Accepted \\
\hline $\mathrm{H} 4$ & $\mathrm{PI} \rightarrow \mathrm{ATT}$ & $0.625^{* * *}$ & 9.081 & Accepted \\
\hline $\mathrm{H} 5$ & $\mathrm{PI} \rightarrow \mathrm{SUP}$ & 0.139 & 1.916 & Rejected \\
\hline H6 & $\mathrm{NI} \rightarrow \mathrm{ATT}$ & $-0.206^{* * *}$ & -3.624 & Accepted \\
\hline $\mathrm{H} 7$ & $\mathrm{NI} \rightarrow \mathrm{SUP}$ & 0.001 & 0.016 & Rejected \\
\hline $\mathrm{H} 8$ & $\mathrm{ATT} \rightarrow \mathrm{SUP}$ & $0.744^{* * *}$ & 8.493 & Accepted \\
\hline \multicolumn{5}{|c|}{$\chi^{2}=300.052(\mathrm{df}=127, p<0.001), \mathrm{RMSEA}=0.072, \mathrm{CFI}=0.939, \mathrm{TLI}=0.927, \mathrm{SRMR}=0.055$} \\
\hline
\end{tabular}

In the relationships between residents' heritage proximity and their perceived impacts, residents' heritage proximity only directly and significantly influenced their perceived positive impact, supporting H1 ( $\beta=0.543$, standardized errors estimated by bootstrapping approach (S.E. boot) $=0.088, p<0.001)$, whereas $\mathrm{H} 2$ was rejected $(\beta=-0.278$, S.E. boot $=0.163, p>0.05)$. In the relationship between residents' heritage proximity and attitude, residents' heritage proximity directly, and significantly influenced attitude, providing support for $\mathrm{H} 3(\beta=0.135$, S.E. boot $=0.056, p<0.05)$. The relationships between perceived impacts and attitude, supporting $\mathrm{H} 4(\beta=0.471$, S.E. boot $=0.052, p<0.001)$, and H6 $(\beta=-0.087$, S.E. boot $=0.024, p<0.001)$ was rejected. The findings also rejected H5 $(\beta=0.099$, S.E. boot $=0.052, p<0.05)$ and H7 $(\beta=0.0$, S.E. boot $=0.021, p>0.05)$, confirming that perceived positive impacts and perceived negative impacts was not positively and significantly related to community support for tourism development. Finally, the relationships between residents' attitude and their support were significant, supporting H8 $(\beta=0.703$, S.E. boot $=0.083, p<0.001)$. 


\section{Conclusions}

For most heritage sites, tourism and heritage development go hand in hand, with tourism development relying on local natural landscapes and/or cultural attractions and bringing economic and social benefits to the heritage site. However, both also collide with tradition and modernity. In other words, tourism can bring bad effects to heritage sites, and the residents of heritage sites may therefore have conflicts and clashes with tourists and tourism managers. Tourism and heritage researchers have conducted numerous studies on heritage site residents and tourists. However, the intangible attributes of intangible cultural heritage $(\mathrm{ICH})$ make it rarely get attention in tourism contexts. Taking the birthplace of Taijiquan (Wen County) as an example, a large number of Taijiquan enthusiasts come to visit and study here every year, even though there are no very famous cultural relics or tourist attractions. Therefore, instead of choosing "spatial distance" as an independent variable in previous studies, this study chose "heritage proximity" to measure the emotional relationship between residents and ICH based on social exchange theory and the immaterial attributes of ICH. Using a sample of residents of ICH tourism sites, this study attempted to incorporate resident heritage proximity (HP) into modeled relationships based on the SET framework of residents' perceived positive impacts (PI) and negative impacts (NI), attitudes (ATT) and support (RS) for ICH tourism. The findings extended the SET and demonstrated the feasibility of the framework in the ICH tourism context.

\subsection{Theoretical Contribution}

This study hypothesized that heritage proximity has an impact on residents' perceived impacts of tourism. The results of the study indicated that the higher the proximity (perceptual distance) of residents to Taijiquan, the more significant the perceived positive impact of $\mathrm{ICH}$ tourism ( $\mathrm{H} 1$ accepted). While hypothesis $2(\mathrm{HP} \rightarrow \mathrm{NI}$ ) was not statistically significant, there was a negative correlation, implying that the closer the residents' proximity (perceptual distance) to Taijiquan, the more likely the ICH tourism negative impact is perceived. This is consistent with the limited research findings on heritage proximity $[18,44]$ that the more local residents identify with the promoted tourism heritage, the more likely they are to view the positive impacts of heritage tourism positively and, at the same time, the more likely they are to view the negative impacts of heritage tourism negatively. It illustrates that cultural heritage, whether tangible or intangible, carries the culture and history of the local community. Community residents are the creators of cultural heritage, while cultural heritage contributes to the cultural confidence and identity of residents. Therefore, residents who feel closer to intangible cultural heritage are more concerned about the authenticity and integrity of cultural heritage than others. At the same time, they are more sensitive to people, events, and phenomena that may affect the sustainability of ICH $[9,43]$.

In addition, this study hypothesized that heritage proximity, positive influence, and negative influence have an effect on residents' attitudes toward tourism, respectively (H3, H4, and H5). The results show that all three hypotheses are valid and confirm the findings of most scholars. Of these, the positive impact is more pronounced on residents attitudes toward tourism as opposed to the negative perception [60]. This indicates that local residents are satisfied with tourism in their area and perceive more benefits than costs from tourism [85]. Not only that, hypothesis 3 was proven, implying that even though residents perceive negative impacts from tourism, they still have a positive attitude towards ICH tourism. As Vargas-Sánchez et al. [86] concluded, despite residents acknowledging some negative impacts of tourism on their community, they tended to demonstrate protourism behavior.

Further, this study hypothesized that the perceived impact of tourism and attitudes have an impact on residents' support behavior, respectively (H6, H7, and H8). However, the results indicate that positive and negative impacts do not directly affect residents support behavior, but indirectly through residents' attitudes. This is consistent with the results of some scholars. For example, Çelik and Rasoolimanesh [87] suggested that residents' negative and positive attitudes toward tourism have direct effects on cost-benefit 
attitudes and indirect effects on support for tourism. But there are discrepancies with the conclusions of other researchers. Some scholars argue that the personal benefits out of tourism development are linked with the support for tourism [56,88]. Furthermore, evidence was also found to support the direct relationship between the perceived benefits of tourism and support of its development in the research of Gursoy et al. [89].

In summary, the theoretical contributions of this study are as follows: firstly, heritage tourism is widely noted as a research hotspot with its stakeholders (managers, residents, tourists). However, in the study of intangible cultural heritage tourism, more attention has been paid to the heirs, but residents have been neglected. The sustainable development of intangible cultural heritage cannot be achieved without the participation of community residents. Therefore, the findings of this study provide theoretical support for enhancing residents' attitudes towards ICH tourism. Secondly, this study introduces the concept of heritage proximity in the context of ICH tourism, which can better explain the antecedents of residents' perceptions of tourism impacts, while enriching the social exchange theory structure. Finally, this study identifies the structure of community residents' attitudes towards ICH tourism development in a developing country context. Theoretical support is added to further expand the boundaries of the concept of sustainable development of intangible cultural heritage.

\subsection{Managerial Implications}

Community-based tourism planning and development approaches are rarely successful in practice because of a host of practical problems, including confusion among residents about complex planning issues and delays that lead to costly decision-making processes [90]. It is therefore particularly important to explore those factors that influence residents' attitudes and support. This study helps destination managers, tourism planners and other groups to better understand residents' perceptions of ICH tourism and how these perceptions influence their support/opposition to tourism development, and provides the necessary background information for application projects.

Heritage proximity indirectly influences residents' support for tourism through their perceived impact on tourism, as well as their attitudes. This means that mechanisms designed by heritage management agencies to promote residents' support for tourism and conservation may not be relevant to them if they do not have a close relationship with the heritage site. This implies that, from a managerial perspective, residents' heritage proximity should all be at the heart of management, development and conservation plans. The local government should invest more ICH-related resources in the community, such as organising more events to promote the active or passive reception of historical and cultural information about ICH by residents, which may increase the perceptual distance between residents and $\mathrm{ICH}$, i.e., enhance their heritage proximity. For example, through large scale events, mass media campaigns and leisure tourism projects, the "healthy" and "nurturing" image of Taijiquan has been recognised not only by the community but also by society.

Furthermore, according to the study, residents' attitudes towards tourism are positive even when tourism has a negative impact. But the positive impact was more pronounced on residents' attitudes towards tourism. As the birthplace of taijiquan, a large number of taijiquan enthusiasts come here every year to study and travel, and many residents are offered jobs as a result. Some students even get into prestigious universities through Taijiquan each year. When residents perceive the benefits from the development of intangible cultural heritage, they are more willing to voluntarily support the sustainable development of ICH. Thus when developing tourism in $\mathrm{ICH}$, positive attitudes towards tourism can be promoted by increasing the investment of resources in the community and upgrading community infrastructure. When the effects of resource investment are perceived by residents, their attitudes will not be hindered by the negative effects of tourism. 


\subsection{Limitations and Further Research}

This study has some limitations and informs the next studies. Firstly, the research sample is from an underdeveloped county in China. Although Taijiquan is well known, the place is not well known as the birthplace. Therefore, the results of the study may not necessarily be generalizable to the more developed cities and regions of China. Furthermore, there are many other factors that influence residents' attitudes and support for tourism, and future researchers may add needed variables to this model to better explain the process, based on TPB and affective SET theories, starting with both rational and emotional aspects. Finally, Taijiquan was only inscribed on the Intangible Cultural Heritage of Humanity list in December 2020, and the tourism industry in this area is only out in the early stages of development, and the community residents have not yet received a more pronounced impact from tourism. Therefore, the development of ICH tourism in this area will be followed up and research will be conducted to reflect the latest situation.

Author Contributions: Conceptualization, Y.W., H.L. and K.-S.P.; methodology, Y.W. and K.-S.P.; software, Y.W. and H.L.; validation, Y.W., H.L. and K.-S.P.; formal analysis, Y.W., H.L. and K.S.P.; investigation, Y.W., H.L. and K.-S.P.; resources, Y.W., H.L. and K.-S.P.; data curation, Y.W., H.L. and K.-S.P.; writing—original draft preparation, Y.W.; writing-review and editing, Y.W., H.L. and K.-S.P.; visualization, Y.W., H.L. and K.-S.P.; supervision, K.-S.P.; project administration, Y.W.; funding acquisition, Y.W. and H.L. All authors have read and agreed to the published version of the manuscript.

Funding: This research received no external funding.

Institutional Review Board Statement: Not applicable.

Informed Consent Statement: Informed consent was obtained from all subjects involved in the study.

Conflicts of Interest: The authors declare no conflict of interest.

\section{References}

1. Su, J. Conceptualising the subjective authenticity of intangible cultural heritage. Int. J. Herit. Stud. 2018, 24, 919-937. [CrossRef]

2. Ghermandi, A.; Camacho-Valdez, V.; Trejo-Espinosa, H. Social media-based analysis of cultural ecosystem services and heritage tourism in a coastal region of Mexico. Tour. Manag. 2020, 77, 104002. [CrossRef]

3. Kearney, A. Intangible cultural heritage: Global awareness and local interest. In Intangible Heritage; Taylor \& Francis Group: London, UK, 2008; pp. 223-240.

4. Petronela, T. The Importance of the Intangible Cultural Heritage in the Economy. Procedia Econ. Financ. 2016, 39, 731-736. [CrossRef]

5. UNESCO Questions \& Answers. 2009. Available online: https://ich.unesco.org/en/kit\#1 (accessed on 10 May 2021).

6. Sinclair-Maragh, G.; Bernard Simpson, S. Heritage tourism and ethnic identity: A deductive thematic analysis of Jamaican Maroons. J. Tour. Herit. Serv. Mark. 2021, 7, 64.

7. Malek, N.M.; Masood, S. Tourism causes uneven development: A case study of Natural and Cultural heritage tourism in Pakistan. J. Adv. Res. Soc. Sci. Humanit. 2018, 4, 06-14.

8. Esfehani, M.H.; Albrecht, J.N. Roles of intangible cultural heritage in tourism in natural protected areas. J. Herit. Tour. 2016, 13, 15-29. [CrossRef]

9. Li, M.; Wu, B.; Cai, L. Tourism development of World Heritage Sites in China: A geographic perspective. Tour. Manag. 2008, 29, 308-319. [CrossRef]

10. Aas, C.; Ladkin, A.; Fletcher, J. Stakeholder collaboration and heritage management. Ann. Tour. Res. 2005, 32, 28-48. [CrossRef]

11. Yang, C.H.; Lin, H.L.; Han, C.C. Analysis of international tourist arrivals in China: The role of World Heritage Sites. Tour Manag 2010, 31, 827-837. [CrossRef]

12. Tan, S.-K.; Tan, S.-H.; Kok, Y.-S.; Choon, S.-W. Sense of place and sustainability of intangible cultural heritage-The case of George Town and Melaka. Tour. Manag. 2018, 67, 376-387. [CrossRef]

13. Gursoy, D.; Chi, C.G.; Dyer, P. Locals' Attitudes toward Mass and Alternative Tourism: The Case of Sunshine Coast, Australia. J. Travel Res. 2009, 49, 381-394. [CrossRef]

14. Kim, S.; Whitford, M.; Arcodia, C. Development of intangible cultural heritage as a sustainable tourism resource: The intangible cultural heritage practitioners' perspectives. J. Herit. Tour. 2019, 14, 422-435. [CrossRef]

15. Nepal, S.K. Residents' Attitudes to Tourism in Central British Columbia, Canada. Tour. Geogr. 2008, 10, 42-65. [CrossRef]

16. Qiu, Q.; Zheng, T.; Xiang, Z.; Zhang, M. Visiting Intangible Cultural Heritage Tourism Sites: From Value Cognition to Attitude and Intention. Sustainability 2019, 12, 132. [CrossRef] 
17. Andereck, K.L.; Valentine, K.M.; Knopf, R.C.; Vogt, C.A. Residents' perceptions of community tourism impacts. Ann. Tour. Res. 2005, 32, 1056-1076. [CrossRef]

18. Lwoga, N.B. Heritage proximity, attitudes to tourism impacts and residents' support for heritage tourism in Kaole Site, Tanzania. Bull. Geogr. Socio-Econ. Ser. 2018, 42, 163-181. [CrossRef]

19. UNECSO Browse the Lists of Intangible Cultural Heritage and the Register of Good Safeguarding Practices. 2020. Available online: https://ich.unesco.org/en/lists\#2020 (accessed on 1 October 2020).

20. Kim, S.-R.; Youn, S.H.; Um, S.-H.; Lee, T.J. The mediation of information technology on visitors' experience at a cultural heritage site. Asia Pac. J. Tour. Res. 2016, 21, 1126-1141. [CrossRef]

21. Tian, D.; Wang, Q.; Law, R.; Zhang, M. Influence of Cultural Identity on Tourists' Authenticity Perception, Tourist Satisfaction, and Traveler Loyalty. Sustainability 2020, 12, 6344. [CrossRef]

22. Yan, W.-J.; Chiou, S.-C. The Safeguarding of Intangible Cultural Heritage from the Perspective of Civic Participation: The Informal Education of Chinese Embroidery Handicrafts. Sustainability 2021, 13, 4958. [CrossRef]

23. $\mathrm{Su}, \mathrm{J}$. Understanding the changing Intangible Cultural Heritage in tourism commodification: The music players' perspective from Lijiang, China. J. Tour. Cult. Chang. 2019, 17, 247-268. [CrossRef]

24. Lin, Q.; Lian, Z. On Protection of Intangible Cultural Heritage in China from the Intellectual Property Rights Perspective. Sustainability 2018, 10, 4369. [CrossRef]

25. Xue, K.; Li, Y.; Meng, X. An evaluation model to assess the communication effects of intangible cultural heritage. J. Cult. Herit. 2019, 40, 124-132. [CrossRef]

26. Lan, T.; Zheng, Z.; Tian, D.; Zhang, R.; Law, R.; Zhang, M. Resident-Tourist Value Co-Creation in the Intangible Cultural Heritage Tourism Context: The Role of Residents' Perception of Tourism Development and Emotional Solidarity. Sustainability 2021, 13, 1369. [CrossRef]

27. Park, E.; Choi, B.-K.; Lee, T.J. The role and dimensions of authenticity in heritage tourism. Tour. Manag. 2019, 74, 99-109. [CrossRef]

28. Del Chiappa, G.; Atzeni, M.; Gallarza, M. Collaborative Policy Making and Stakeholder Engagement: A Resident-Based Perspective. In Tourist Destination Management: Instruments, Products, and Case Studies; Kozak, N., Kozak, M., Eds.; Springer: New York, NY, USA, 2019; pp. 193-207.

29. Del Chiappa, G.; Atzeni, M. Collaborative policy making: A community-based perspective in the context of Sardinia's Maddalena Archipelago, Italy. In Collaboration in Tourism Businesses and Destinations: A Handbook; Emerald Group Publishing: Bingley, UK, 2015; pp. 57-74.

30. Del Chiappa, G.; Atzeni, M.; Ghasemi, V. Community-based collaborative tourism planning in islands: A cluster analysis in the context of Costa Smeralda. J. Destin. Mark. Manag. 2018, 8, 41-48. [CrossRef]

31. Li, B.; Mi, Z.; Zhang, Z. Willingness of the new generation of farmers to participate in rural tourism: The role of perceived impacts and sense of place. Sustainability 2020, 12, 766. [CrossRef]

32. Koldijk, L. Cultural Heritage Proximity and Its Effect on Subjective Well-Being: A Case Study in Groningen, The Netherlands. Bachelor Thesis, University of Groningen, Groningen, The Netherlands, 2021.

33. Andrade-Suárez, M.; Caamaño-Franco, I. The Relationship between industrial heritage, wine tourism, and sustainability: A case of local community perspective. Sustainability 2020, 12, 7453. [CrossRef]

34. Krishnaswamy, J.; Abdullah, D.; Wen, T.C. An empirical study on residents' place image and perceived impacts on support for tourism development in Penang, Malaysia. Int. J. Acad. Res. Bus. Soc. Sci 2018, 8, 178-198.

35. Zhang, T.; Yin, P.; Peng, Y. Effect of Commercialization on Tourists' Perceived Authenticity and Satisfaction in the Cultural Heritage Tourism Context: Case Study of Langzhong Ancient City. Sustainability 2021, 13, 6847. [CrossRef]

36. Torre, A.; Rallet, A. Proximity and localization. Reg. Stud. 2005, 39, 47-59. [CrossRef]

37. Kim, Y.-J.; Kang, S.-W. Perceived Crowding and Risk Perception According to Leisure Activity Type during COVID-19 Using Spatial Proximity. Int. J. Environ. Res. Public Health 2021, 18, 457. [CrossRef]

38. Jurowski, C.; Gursoy, D. DISTANCE EFFECTS ON RESIDENTS' ATTITUDES TOWARD TOURISM. Ann. Tour. Res. 2004, 31, 296-312. [CrossRef]

39. Sharma, B.; Dyer, P. An investigation of differences in residents' perceptions on the Sunshine Coast: Tourism impacts and demographic variables. Tour. Geogr. 2009, 11, 187-213. [CrossRef]

40. Belisle, F.J.; Hoy, D.R. The perceived impact of tourism by residents a case study in Santa Marta, Colombia. Ann. Tour. Res. 1980, 7, 83-101. [CrossRef]

41. McKercher, B. The impact of distance on tourism: A tourism geography law. Tour. Geogr. 2018, 20, 905-909. [CrossRef]

42. Williams, J.; Lawson, R. Community issues and resident opinions of tourism. Ann. Tour. Res. 2001, 28, 269-290. [CrossRef]

43. Uriely, N.; Israeli, A.A.; Reichel, A. Heritage proximity and resident attitudes toward tourism development. Ann. Tour. Res. 2002, 29, 859-861. [CrossRef]

44. Lwoga, N.B. Moderating effect of heritage spatial proximity on the relationship between perceptual proximity and residents' attitudes towards tourism. Afr. Geogr. Rev. 2019, 38, 268-282. [CrossRef]

45. Martín Martín, J.M.; Guaita Martinez, J.M.; Salinas Fernandez, J.A. An analysis of the factors behind the citizen's attitude of rejection towards tourism in a context of overtourism and economic dependence on this activity. Sustainability $2018,10,2851$. [CrossRef] 
46. Tournois, L.; Djeric, G. Evaluating urban residents' attitudes towards tourism development in Belgrade (Serbia). Curr. Issues Tour. 2019, 22, 1670-1678. [CrossRef]

47. Black, R.; Cobbinah, P.B. Local attitudes towards tourism and conservation in rural Botswana and Rwanda. J. Ecotour. 2018, 17, 79-105. [CrossRef]

48. Chin, C.-H.; Law, F.-Y.; Lo, M.-C.; Ramayah, T. The Impact of Accessibility Quality and Accommodation Quality on Tourists' Satisfaction and Revisit Intention to Rural Tourism Destination in Sarawak: The Moderating Role of Local Communities' Attitude. Glob. Bus. Manag. Res. 2018, 10, 115-127.

49. Merli, R.; Preziosi, M.; Acampora, A.; Lucchetti, M.; Ali, F. The impact of green practices in coastal tourism: An empirical investigation on an eco-labelled beach club. Int. J. Hosp. Manag. 2019, 77, 471-482. [CrossRef]

50. López, M.F.B.; Virto, N.R.; Manzano, J.A.; Miranda, J.G.-M. Residents' attitude as determinant of tourism sustainability: The case of Trujillo. J. Hosp. Tour. Manag. 2018, 35, 36-45. [CrossRef]

51. Yuan, Q.; Song, H.; Chen, N.; Shang, W. Roles of tourism involvement and place attachment in determining residents' attitudes toward industrial heritage tourism in a resource-exhausted city in China. Sustainability 2019, 11, 5151. [CrossRef]

52. Hadinejad, A.; Moyle, B.D.; Scott, N.; Kralj, A.; Nunkoo, R. Residents' attitudes to tourism: A review. Tour. Rev. 2019, 74, 150-165. [CrossRef]

53. Choi, H.C.; Murray, I. Resident attitudes toward sustainable community tourism. J. Sustain. Tour. 2010, 18, 575-594. [CrossRef]

54. Kelley, H.H.; Thibaut, J.W. Interpersonal Relations: A Theory of Interdependence; Wiley: New York, NY, USA, 1978.

55. Eusébio, C.; Vieira, A.L.; Lima, S. Place attachment, host-tourist interactions, and residents' attitudes towards tourism development: The case of Boa Vista Island in Cape Verde. J. Sustain. Tour. 2018, 26, 890-909. [CrossRef]

56. Rashid, I. Resident attitudes towards support for future tourism: Utilising the Social Exchange Theory (SET). J. Tour. Hosp. Culin. Arts 2020, 12, 106-111.

57. Kim, K.; Uysal, M.; Sirgy, M.J. How does tourism in a community impact the quality of life of community residents? Tour. Manag. 2013, 36, 527-540. [CrossRef]

58. Özel, Ç.H.; Kozak, N. An exploratory study of resident perceptions toward the tourism industry in Cappadocia: A Social Exchange Theory approach. Asia Pac. J. Tour. Res. 2017, 22, 284-300. [CrossRef]

59. Abdollahzadeh, G.; Sharifzadeh, A. Rural residents' perceptions toward tourism development: A study from Iran. Int. J. Tour. Res. 2014, 16, 126-136. [CrossRef]

60. Jani, D. Residents' perception of tourism impacts in Kilimanjaro: An integration of the Social Exchange Theory. Tour. Int. Interdiscip. J. 2018, 66, 148-160.

61. M Ghoochani, O.; Ghanian, M.; Khosravipour, B.; Crotts, J. Explaining a Framework for Expanding Support for the Development of Rural Tourism Based on the Integration of Social Exchange and Place Image Theories (Case Study: Villages in the Wetland Areas of the Khuzestan Province. J. Rural Res. 2019, 10, 452-469.

62. Ribeiro, M.A.; Pinto, P.; Silva, J.A.; Woosnam, K.M. Residents' attitudes and the adoption of pro-tourism behaviours: The case of developing island countries. Tour. Manag. 2017, 61, 523-537. [CrossRef]

63. Ko, D.-W.; Stewart, W.P. A structural equation model of residents' attitudes for tourism development. Tour. Manag. 2002, 23, 521-530. [CrossRef]

64. Zhu, H.; Liu, J.; Wei, Z.; Li, W.; Wang, L. Residents' attitudes towards sustainable tourism development in a historical-cultural village: Influence of perceived impacts, sense of place and tourism development potential. Sustainability 2017, 9, 61. [CrossRef]

65. Du, Z; Su, Q. Study on the relationship between the community participation of rural tourism, residents' perceived tourism impact and sense of community involvement-A case study of Anji rural tourism destination, Zhejiang Province. Tour. Trib. 2011, $26,65-70$.

66. Chen, N.; Wang, Y.; Li, J.; Wei, Y.; Yuan, Q. Examining structural relationships among night tourism experience, lovemarks, brand satisfaction, and brand loyalty on "Cultural Heritage night" in South Korea. Sustainability 2020, 12, 6723. [CrossRef]

67. Tam, F.; Tsai, H.; Chen McCain, S.-L. Tourists' and residents' perceptions toward casino gaming development in Hong Kong. Asia Pac. J. Tour. Res. 2013, 18, 385-407. [CrossRef]

68. Xiaoli, C. Taijiquan Enshrined among World's Intangible Cultural Heritages. In Xinhua. 2020. Available online: http://www. xinhuanet.com/english/2020-12/19/c_139603104.htm (accessed on 1 October 2020).

69. Lin, Z.; Chen, Y.; Filieri, R. Resident-tourist value co-creation: The role of residents' perceived tourism impacts and life satisfaction. Tour. Manag. 2017, 61, 436-442. [CrossRef]

70. Stylidis, D.; Biran, A.; Sit, J.; Szivas, E.M. Residents' support for tourism development: The role of residents' place image and perceived tourism impacts. Tour. Manag. 2014, 45, 260-274. [CrossRef]

71. Liang, Z.-X.; Hui, T.-K. Residents' quality of life and attitudes toward tourism development in China. Tour. Manag. 2016, 57, 56-67. [CrossRef]

72. Hair, E.; Halle, T.; Terry-Humen, E.; Lavelle, B.; Calkins, J. Children's school readiness in the ECLS-K: Predictions to academic, health, and social outcomes in first grade. Early Child. Res. Q. 2006, 21, 431-454. [CrossRef]

73. Hair, J.F. Multivariate Data Analysis; Prentice Hall: Upper Saddle River, NJ, USA, 2009.

74. Bentler, P.M.; Chou, C.-P. Practical issues in structural modeling. Sociol. Methods Res. 1987, 16, 78-117. [CrossRef]

75. Fabrigar, L.R.; Wegener, D.T.; MacCallum, R.C.; Strahan, E.J. Evaluating the use of exploratory factor analysis in psychological research. Psychol. Methods 1999, 4, 272. [CrossRef] 
76. Peterson, R.A. A meta-analysis of Cronbach's coefficient alpha. J. Consum. Res. 1994, 21, 381-391. [CrossRef]

77. Byrne, B.M.; Stewart, S.M. Teacher's corner: The MACS approach to testing for multigroup invariance of a second-order structure: A walk through the process. Struct. Equ. Modeling 2006, 13, 287-321. [CrossRef]

78. Hu, L.-t.; Bentler, P.M.; Kano, Y. Can test statistics in covariance structure analysis be trusted? Psychol. Bull. 1992, $112,351$. [CrossRef]

79. Jöreskog, K.G.; Sörbom, D. LISREL 7: A Guide to the Program and Applications; SPSS Inc.: Chicago, IL, USA, 1989.

80. Kline, R.B. Principles and Practice of Structural Equation Modeling; Guilford Publications: New York, NY, USA, 2015.

81. Bentler, P.M.; Bonett, D.G. Significance tests and goodness of fit in the analysis of covariance structures. Psychol. Bull. 1980, 88, 588. [CrossRef]

82. Loehlin, J.C.; Beaujean, A.A. Latent Variable Models: An Introduction to Factor, Path, and Structural Equation Analysis; Taylor \& Francis: New York, NY, USA, 2016.

83. Anderson, J.C.; Gerbing, D.W.J.P.b. Structural equation modeling in practice: A review and recommended two-step approach. Psychol. Bull. 1988, 103, 411. [CrossRef]

84. Podsakoff, P.M.; MacKenzie, S.B.; Lee, J.-Y.; Podsakoff, N.P. Common method biases in behavioral research: A critical review of the literature and recommended remedies. J. Appl. Psychol. 2003, 88, 879. [CrossRef] [PubMed]

85. Chen, C.-F.; Chen, P.-C. Resident attitudes toward heritage tourism development. Tour. Geogr. 2010, 12, 525-545. [CrossRef]

86. Vargas-Sánchez, A.; do Valle, P.O.; da Costa Mendes, J.; Silva, J.A. Residents' attitude and level of destination development: An international comparison. Tour. Manag. 2015, 48, 199-210. [CrossRef]

87. Çelik, S.; Rasoolimanesh, S.M. Residents' Attitudes towards Tourism, Cost-Benefit Attitudes, and Support for Tourism: A Pre-development Perspective. Tour. Plan. Dev. 2021, 1-19. [CrossRef]

88. Kang, S.K.; Lee, J. Support of marijuana tourism in Colorado: A residents' perspective using social exchange theory. J. Destin. Mark. Manag. 2018, 9, 310-319. [CrossRef]

89. Gursoy, D.; Jurowski, C.; Uysal, M. Resident attitudes: A structural modeling approach. Ann. Tour. Res. 2002, 29, 79-105. [CrossRef]

90. Schofield, P. City resident attitudes to proposed tourism development and its impacts on the community. Int. J. Tour. Res. 2011, 13, 218-233. [CrossRef] 